\title{
PENGARUH MODEL PEMBELAJARAN INKUIRI MENGGUNAKAN SIMULASI PhET TERHADAP HASIL BELAJAR SISWA PADA MATERI POKOK OPTIKA GEOMETRIS DI KELAS X SMAN 2 KABANJAHE T.P. 2014/2015
}

\author{
Jonny Haratua Panggabean dan Ira Kesuma Sari Tampubolon \\ Jurusan Fisika FMIPA Universitas Negeri Medan \\ Jalan Willem Iskandar Pasar V Medan, Sumatera Utara \\ gabejhp@gmail.com
}

\begin{abstract}
ABSTRAK
Penelitian ini bertujuan untuk mengetahui pengaruh model pembelajaran inkuiri menggunakan simulasi PhET terhadap hasil belajar siswa pada materi pokok Optika Geometris di kelas X SMAN 2 Kabanjahe T.P. 2014/2015. Jenis penelitian ini adalah quasi experiment dengan two group pre-test and pos-test design. Pengambilan sampel dilakukan dengan cara cluster random sampling dengan mengambil dua kelas dari lima kelas secara acak, yaitu kelas X PMIA-3 sebagai kelas eksperimen dan kelas X PMIA-4 sebagai kelas kontrol. Instrumen yang digunakan berupa tes hasil belajar dalam ranah kognitif berbentuk uraian yang terdiri dari 8 soal yang sudah divalidasi dan lembar observasi untuk mengukur aktivitas. Hasil penelitian menunjukkan bahwa ada pengaruh model pembelajaran inkuiri menggunakan simulasi PhET terhadap hasil belajar. Rata-rata keseluruhan nilai aktivitas belajar siswa adalah 68,23\% termasuk kategori cukup aktif. Berdasarkan data yang diperoleh, maka dapat disimpulkan bahwa ada perbedaan akibat pengaruh model pembelajaran inkuiri menggunakan simulasi PhET terhadap hasil belajar dan aktivitas belajar siswa pada materi pokok Optika Geometris di kelas X SMAN 2 Kabanjahe T.P. 2014/2015.
\end{abstract}

Kata kunci : model pembelajaran inkuiri dan hasil belajar.

\begin{abstract}
This research is aimed to determine the effect of inquiry learning model using PhET simulations toward student's learning outcomes in the subject matter geometrical optics in class X SMAN 2 Kabanjahe T.P. 2014/2015. This research is a quasi experiment with two group pre-test and post-test design. Sampling was done by cluster random sampling by taking two classes at random from five classes, namely class X PMIA-3 as the experimental class and the class X PMIA-4 as the control class. Instruments used in the form of test results in cognitive learning form description consists of 8 questions that have been validated and observation sheets to measure the activity. The results showed that there is influence of inquiry learning model using PhET simulations on learning outcomes. The overall average value of student learning activity was $68.23 \%$ are active enough. Based on the data obtained, it can be concluded that there is a difference due to the influence of inquiry learning model using PhET simulations for learning outcomes and learning activities of students in the subject matter geometrical optics in class X SMAN 2 Kabanjahe T.P. 2014/2015.
\end{abstract}

Keywords : inquiry learning model and learning outcomes. 


\section{PENDAHULUAN}

Pendidikan merupakan suatu investasi bagi pengembangan sumber daya manusia sebagai individu dan anggota masyarakat. Dewasa ini pengembangan kualitas sumber daya manusia menjadi suatu keharusan, terutama dalam memasuki era globalisasi dan kemajuan Ilmu Pengetahuan dan Teknologi (IPTEK). Untuk dapat memasuki era globalisasi dan menyerap kemajuan teknologi tiada jalan lain selain melalui pendidikan. Seiring dengan kemajuan zaman maka perkembangan ilmu pengetahuan dan teknologi memegang peranan yang sangat besar. Fisika merupakan salah satu cabang dari ilmu sains yang sangat berperan penting dalam perkembangan IPTEK tersebut. Fisika merupakan hasil kegiatan manusia berupa pengetahuan, gagasan, dan konsep yang terorganisasi tentang alam sekitar yang diperoleh dari serangkaian pengalaman melalui proses ilmiah. Pelajaran fisika tidak cukup hanya mempelajari produk tetapi menekankan bagaimana produk itu diperoleh, baik sebagai proses ilmiah maupun pengembangan sikap ilmiah siswa. Untuk itu hasil belajar tidak hanya terbatas pada ranah kognitif, tetapi juga ranah psikomotor dan ranah afektif (Prihatiningtyas, dkk., 2013).

Pembelajaran fisika dewasa ini masih belum dapat dikatakan baik karena masih bersifat hapalan dan kurang mengembangkan proses berpikir. Pada umumnya siswa tidak merasakan keterlibatan penalaran dalam mempelajarinya. Ada beberapa faktor yang menyebabkan hal tersebut salah satunya yaitu metode mengajar yang digunakan guru di dalam kelas belum mampu menciptakan kondisi optimal pada berlangsungnya pembelajaran, dimana selama ini guru kebanyakan hanya menggunakan metode ceramah. Media pembelajaran yang digunakan masih kurang bervariasi karena hanya mengandalkan buku teks sehingga siswa hanya mendengarkan guru menjelaskan materi pelajaran fisika.

Berdasarkan hasil wawancara penulis dengan seorang guru mata pelajaran fisika di SMAN 2 Kabanjahe, diperoleh informasi bahwa pembelajaran fisika di dalam kelas lebih dominan dengan pemberian materi atau teori-teori fisika. Di samping itu, metode pembelajaran yang diberikan guru kurang bervariasi karena didominasi oleh pembelajaran konvensional yaitu dengan metode ceramah. Aktivitas belajar siswa juga masih rendah karena selama proses pembelajaran siswa jarang melakukan percobaan atau eksperimen yang juga dikarenakan keterbatasan alat dan tidak ada laboratorium khusus fisika di sekolah. Selain itu, berdasarkan pengalaman penulis selama duduk di bangku SMA dan saat melakukan observasi awal, pembelajaran fisika juga masih dominan menggunakan media pembelajaran seperti buku, dan papan tulis.

Hal tersebut menyebabkan siswa menjadi kurang aktif dan kreatif, sehingga pelajaran fisika menjadi membosankan dan menjadi salah satu pelajaran yang sulit dipelajari dan tidak disukai oleh siswa. Akibatnya siswa kurang mampu memahami, menerapkan dan menganalisis konsep fisika dalam kehidupan sehari-hari. Akhirnya, siswa cenderung memusatkan pembelajaran kepada guru (teacher centered) dan hal ini yang memicu rendahnya aktivitas dan hasil belajar siswa pada mata pelajaran fisika.

Kondisi seperti ini harus segera diperbaiki. Salah satu diantaranya melalui perbaikan kegiatan pembelajaran dengan tindakan yang dapat mengubah suasana pembelajaran yang melibatkan siswa secara aktif, yaitu dengan menggunakan model pembelajaran inkuiri. Model ini mengarahkan siswa untuk bisa menemukan masalah dan kemudian mampu memecahkan masalah yang ditemukan tersebut secara ilmiah. Gulo (2002) menyatakan bahwa model pembelajaran inkuiri berarti suatu rangkaian kegiatan 
belajar yang melibatkan secara maksimal seluruh kemampuan siswa untuk mencari dan menyelidiki secara sistematis, kritis, logis, analitis, sehingga siswa dapat merumuskan sendiri penemuannya dengan penuh percaya diri. Oleh sebab itu, siswa lebih banyak belajar sendiri, mengembangkan kreativitas dalam memecahkan masalah, dan siswa ditempatkan sebagai subjek yang belajar.

Penerapan model pembelajaran inkuiri dapat lebih efektif dengan menggunakan media dalam kegiatan pembelajaran. Guru yang efektif dalam menggunakan media dapat meningkatkan minat siswa dalam proses belajar mengajar dan siswa akan lebih cepat dan mudah memahami dan mengerti terhadap materi pelajaran yang disampaikan guru (Sabri, 2010). Media yang digunakan berupa simulasi virtual yaitu simulasi Physics Education Technology (PhET). Simulasi PhET sangat efektif untuk membantu siswa dalam membangun pemahaman dan intuisi untuk fenomena yang bersifat abstrak. Simulasi PhET yang akan peneliti gunakan adalah Geometric Optics. Kelebihan simulasi PhET dapat mengetahui jalannya sinar pada lensa hanya dengan menggesergeser letak benda dan mengukur panjang lintasan letak benda sehingga dapat langsung mengetahui jarak bayangan dan sifat bayangan.

Penelitian menggunakan model pembelajaran inkuiri sudah pernah dilakukan oleh peneliti sebelumnya. Penelitian dengan model pembelajaran inkuiri pernah dilakukan oleh Bukit (2012) dan Sirait (2012). Secara umum, kesimpulan dari penelitian yang telah dilakukan oleh peneliti sebelumnya adalah terdapat pengaruh signifikan penggunaan model pembelajaran inkuiri terhadap aktivitas belajar dan hasil belajar siswa. Namun demikian, kedua peneliti tersebut tidak menggunakan media pembelajaran dalam penelitiannya. Sementara itu, penelitian oleh Sirait (2012) juga belum mengukur aktivitas belajar siswa selama proses pembelajaran. Oleh sebab itu, penulis melakukn penelitian ini dengan tujuan untuk mengetahui pengaruh model pembelajaran inkuiri menggunakan simulasi PhET terhadap hasil belajar siswa pada materi pokok Optika Geometris di kelas $\mathrm{X}$ SMAN 2 Kabanjahe T.P. 2014/2015.

\section{METODE PENELITIAN}

Jenis penelitian ini adalah quasi exsperiment dengan desain penelitian pretest-posttest control group design. Populasi dalam penelitian ini adalah seluruh siswa kelas X-PMIA di SMAN 2 Kabanjahe T.P. 2014/2015 yang terdiri dari lima kelas. Pengambilan sampel dilakukan secara acak (cluster random sampling). Sampel dalam penelitian diambil dua kelas dari populasi. Kelas X-3 PMIA dijadikan sebagai kelas eksperimen yaitu kelas yang akan diajarkan menggunakan model pembelajaran inkuiri menggunakan simulasi PhET, dan kelas X-4 PMIA dijadikan sebagai kelas kontrol yaitu kelas yang akan diajarkan menggunakan pembelajaran konvensional.

Instrumen tes yang digunakan dalam penelitian ini adalah tes hasil belajar berupa soal essay dan lembar observasi. Tes hasil belajar digunakan untuk mengetahui kemampuan siswa pada tingkat kognitif, sedangkan lembar observasi digunakan sebagai panduan observasi mengenai aktivitas belajar siswa selama kegiatan pembelajaran berlangsung. Tes hasil belajar siswa dalam bentuk essai berjumlah 8 soal. Tes hasil belajar divalidasi terlebih dahulu dengan validitas isi dan uji ramalan.

\section{Hasil dan Pembahasan Hasil Penelitian}

Adapun hasil pretes dari kedua kelas sebelum diberi perlakuan pada kelas eksperimen dan kelas kontrol ditunjukkan pada Tabel 1

Tabel 1. Data Pretes Kelas Eksperimen dan Kelas Kontrol.

\begin{tabular}{|c|c|c|c|c|c|c|c|c|}
\hline Interval & \multicolumn{3}{|c|}{ Kelas Eksperimen } & \multicolumn{4}{|c|}{ Kelas kontrol } \\
\cline { 2 - 8 } Nilai & $\boldsymbol{f}$ & & $\boldsymbol{S}^{2}$ & $\boldsymbol{S}$ & $\boldsymbol{f}$ & & $\boldsymbol{S}^{2}$ & $\boldsymbol{S}$ \\
\hline $6-11$ & 7 & 20,09 & 95,26 & 9,76 & 1 & 16,39 & 55,16 & 7,34 \\
& & & & & 0 & & & \\
\hline
\end{tabular}




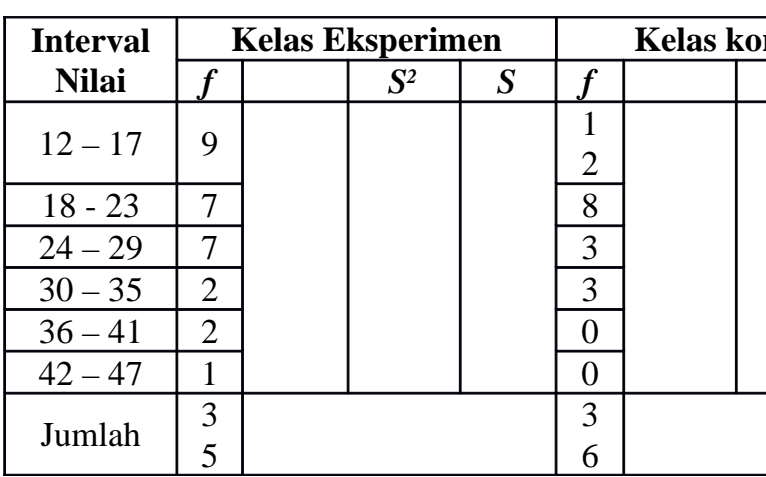

Ringkasan uji normalitas dan homogenitas data pretes kelas eksperimen dan kontrol ditunjukkan pada Tabel 2.

Tabel 2. Ringkasan hasil perhitungan uji normalitas dan homogenitas data pretes kelas eksperimen dan kontrol.

\begin{tabular}{|c|c|c|c|}
\hline $\begin{array}{c}\text { Data } \\
\text { Pretes }\end{array}$ & $\begin{array}{c}\text { Kelas } \\
\text { Eksperimen }\end{array}$ & $\begin{array}{c}\text { Kelas } \\
\text { Kontrol }\end{array}$ & $\begin{array}{c}\text { Kesim- } \\
\text { pulan }\end{array}$ \\
\hline $\mathrm{L}_{\text {hitung }}$ & 0,1199 & 0,1310 & Normal \\
\hline $\mathrm{L}_{\text {tabel }}$ & 0,1498 & 0,1477 & Normal \\
\hline $\mathrm{F}_{\text {hitung }}$ & \multicolumn{2}{|c|}{1,726} & Homo- \\
& \multicolumn{2}{|c|}{1,766} & gen \\
\hline $\mathrm{F}_{\text {tabel }}$ & \multicolumn{2}{|c}{} \\
\hline
\end{tabular}

Uji hipotesis dua pihak (uji kesamaan rata-rata) digunakan untuk mengetahui kesamaan kemampuan awal siswa pada kedua kelompok sampel. Ringkasan uji kesamaan rata rata pretes ditunjukkan pada Tabel 3.

Tabel 3. Ringkasan perhitungan uji hipotesis data pretes.

\begin{tabular}{|c|c|c|c|}
\hline $\begin{array}{c}\text { Data } \\
\text { Pretes }\end{array}$ & $\begin{array}{c}\text { Rata- } \\
\text { rata }\end{array}$ & $\mathbf{t}_{\text {hitung }}$ & $\mathbf{t}_{\text {tabel }}$ \\
\hline $\begin{array}{c}\text { Kelas } \\
\text { Eksperim } \\
\text { en }\end{array}$ & 20,09 & & \\
\cline { 1 - 2 } $\begin{array}{c}\text { Kelas } \\
\text { Kontrol }\end{array}$ & 16,39 & 1,997 \\
\hline
\end{tabular}

Berdasarkan Tabel 3, $\mathrm{t}_{\text {hitung }}<\mathrm{t}_{\text {tabel }}$ yang berarti kemampuan awal kedua kelas atau kelompok sampel adalah sama.

Setelah dilakukan pretes, selanjutnya kedua kelas diberi perlakuan berbeda. Pada kelas eksperimen diberi perlakukan yaitu model pembelajaran inkuiri dan kelas kontrol diberi perlakuan yaitu pembelajaran konvensional. Dalam tpobses pembelajaran model inkuiri dilakukan observasi. Observasi dimaksudkan untuk mengamati aktivitas belajar siswa selama pembelajaran. Ringkasan hasil observasi aktivitas belajar siswa pada pertemuan I, II, III, dan IV dapat dilihat pada Tabel 5.

Tabel 4. Hasil observasi aktivitas belajar siswa kelas eksperimen.

\begin{tabular}{|c|c|c|}
\hline $\begin{array}{c}\text { Pertemu } \\
\text { an ke- }\end{array}$ & $\begin{array}{c}\text { Rata-rata } \\
\text { Nilai } \\
\text { Aktivitas }\end{array}$ & Kategori \\
\hline I & $50,54 \%$ & Kurang aktif \\
\hline II & $65,48 \%$ & Cukup aktif \\
\hline III & $76,90 \%$ & Aktif \\
\hline IV & $80,00 \%$ & Sangat Aktif \\
\hline
\end{tabular}

Tabel 4 dapat juga disajikan dalam bentuk diagram seperti yang ditunjukkan pada Gambar 1.

Gambar 1. Diagram batang aktivitas belajar siswa.

Gambar 1 menunjukkan bahwa terdapat peningkatan aktivitas belajar siswa dari pertemuan pertama, kedua, ketiga, dan keempat. Rata-rata keseluruhan nilai aktivitas belajar siswa selama mengikuti proses pembelajaran adalah $68,23 \%$ dengan kategori cukup aktif.

Setelah selesai melakukan pembelajaran pada kelas eksperimen dan kelas kontrol, kedua kelas selanjutnya diberikan postes dengan soal yang sama seperti soal pretes. Data postes kelas eksperimen dan kontrol ditunjukkan pada Tabel 5. 
Tabel 5. Ringkasan Data Postes Kelas Eksperimen dan Kontrol.

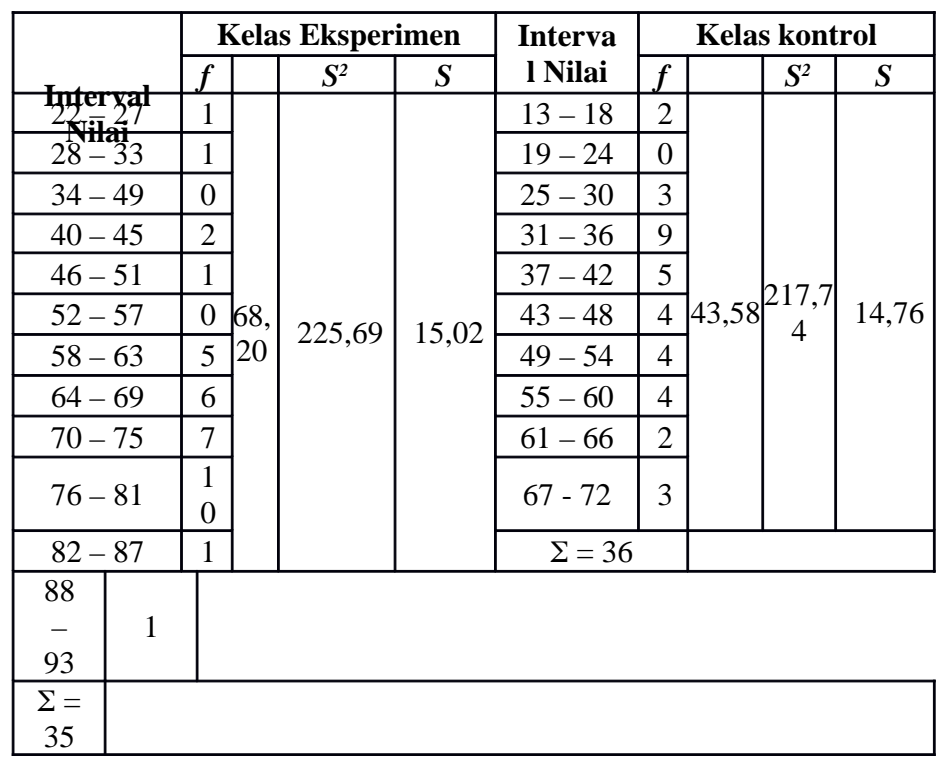

Ringkasan uji normalitas dan homogenitas data postes kelas eksperimen dan kontrol ditunjukkan pada Tabel 6.

Tabel 6. Ringkasan hasil perhitungan uji normalitas dan homogenitas data postes kelas eksperimen dan kontrol.

\begin{tabular}{|c|c|c|c|}
\hline $\begin{array}{c}\text { Data } \\
\text { Postes }\end{array}$ & $\begin{array}{c}\text { Kelas } \\
\text { Eksperimen }\end{array}$ & $\begin{array}{c}\text { Kelas } \\
\text { Kontrol }\end{array}$ & $\begin{array}{c}\text { Kesim- } \\
\text { pulan }\end{array}$ \\
\hline $\mathrm{L}_{\text {hitung }}$ & 0,1406 & 0,1311 & Normal \\
\hline $\mathrm{L}_{\text {tabel }}$ & 0,1498 & 0,1477 & Normal \\
\hline $\mathrm{F}_{\text {hitung }}$ & \multicolumn{2}{|c|}{1,037} & Homo- \\
gen
\end{tabular}

Uji hipotesis satu pihak digunakan untuk mengetahui adanya pengaruh dari suatu perlakuan yaitu model pembelajaran inkuiri menggunakan simulasi PhET terhadap hasil belajar siswa.

Kriteria pengujian yang berlaku ialah : terima $H_{o}$ jika $t<t_{1-\alpha}$, dimana $t_{1-\alpha}$ didapat dari daftar distribusi $\mathrm{t}$ dengan $\mathrm{dk}=$ ( $\mathrm{n} \square+\mathrm{n} \square-2)$ dan peluang ( $\mathrm{t} \square-\alpha)$ dan $\alpha=0,05$ (Sudjana, 2005). Jika t mempunyai hargaharga lain $\mathrm{H} \square$ di tolak, yang berarti bahwa ada pengaruh yang disignifikan dari model pembelajaran inkuiri terhadap hasil belajar siswa. Ringkasan hasil uji t data postes ditunjukkan pada Tabel 7.

Tabel 7. Ringkasan perhitungan uji hipotesis data postes siswa.

\begin{tabular}{|c|c|c|c|}
\hline $\begin{array}{c}\text { Data } \\
\text { Postes }\end{array}$ & $\begin{array}{c}\text { Rata- } \\
\text { rata }\end{array}$ & $\mathbf{t}_{\text {hitung }}$ & $\mathbf{t}_{\text {tabel }}$ \\
\hline $\begin{array}{c}\text { Kelas } \\
\text { Eksperim } \\
\text { en }\end{array}$ & 68,20 & 6,889 & 1,997 \\
\hline $\begin{array}{c}\text { Kelas } \\
\text { Kontrol }\end{array}$ & 43,58 & & \\
\hline
\end{tabular}

Berdasarkan analisis data pada Tabel 7, dapat disimpulkan bahwa ada pengaruh yang signifikan model pembelajaran inkuiri menggunakan simulasi PhET terhadap hasil belajar siswa.

\section{PEMBAHASAN}

Hasil penelitian pretes menunjukkan bahwa pada kondisi awal kedua kelas sampel memiliki kemampuan yang sama kemudian kedua sampel tersebut diberi perlakuan yang berbeda. Pada kelas eksperimen diberikan perlakuan dengan model pembelajaran inkuiri menggunakan simulasi PhET dan pada kelas kontrol diberikan perlakukan dengan pembelajaran konvensional.

Hasil akhir penelitian menunjukkan bahwa ada pengaruh yang signifikan terhadap hasil belajar siswa menggunakan model pembelajaran inkuiri menggunakan simulasi PhET pada materi pokok optika geometris di kelas X PMIA SMAN 2 Kabanjahe. Hal ini dinyatakan berdasarkan pada perolehan nilai rata-rata postes siswa kelas eksperimen 68,20, sedangkan siswa untuk di kelas kontrol sebesar 43,58. Hasil uji hipotesis data postes diperoleh kesimpulan bahwa ada pengaruh model pembelajaran inkuiri menggunakan simulasi PhET terhadap hasil belajar siswa. Ini membuktikan hasil belajar siswa yang menggunakan model pembelajaran inkuiri lebih baik daripada pembelajaran konvensional.

Proses penilaian selama kegiatan belajar mengajar berlangsung, tidak hanya untuk mengetahui hasil belajar siswa tetapi 
juga dilakukan pengamatan aktivitas belajar siswa di kelas eksperimen dengan menggunakan lembar observasi. Tujuannya untuk mengetahui bagaimana aktivitas belajar siswa selama mengikuti pembelajaran dengan model pembelajaran inkuiri menggunakan simulasi PhET pada materi Optik Geometris.

Aktivitas belajar siswa yang diamati oleh observer mengalami peningkatan siswa dari pertemuan pertama, kedua, ketiga, hingga pertemuan keempat. Secara keseluruhan, nilai rata-rata aktivitas belajar siswa pada kelas eksperimen sebesar 68,23\% termasuk kategori cukup aktif. Data tersebut menunjukkan bahwa dengan menggunakan model pembelajaran inkuiri dapat meningkatkan aktivitas siswa. Hal ini sejalan dengan pernyataan Trianto (2010) dalam bukunya bahwa sasaran utama kegiatan pembelajaran inkuiri adalah (1) keterlibatan siswa secara maksimal dalam proses kegiatan belajar; (2) keterarahan kegiatan secara logis dan sistematis pada tujuan pembelajaran, dan (3) mengembangkan sikap percaya diri pada siswa tentang apa yang ditemukan dalam proses inkuiri.

Hasil belajar siswa di kelas eksperimen yang menggunakan model pembelajaran inkuiri menggunakan simulasi PhET menunjukkan hasil yang lebih baik dibandingkan kelas yang menggunakan pembelajaran konvensional karena siswa menjadi senang mengikuti pembelajaran. Siswa senang karena siswa diberikan kesempatan untuk menemukan sendiri inti dari materi pelajaran dengan melakukan penyelidikan (percobaan). Rasa senang membuat siswa menjadi lebih aktif. Siswa aktif dalam mencari informasi, memahami materi yang dipelajari baik melalui buku pelajaran maupun media pembelajaran lainnya. Siswa menjadi kompak dengan teman kelompoknya dan saling bekerjasama dalam penyelidikan dan siswa saling memberikan masukan satu sama lain. Hal ini sesuai dengan pernyataan McKagan, et al. (2008) yang menyatakan bahwa simulasi PhET sangat efektif untuk membantu siswa dalam membangun pemahaman dan intuisi untuk fenomena yang bersifat abstrak.

Meningkatnya hasil belajar siswa juga tidak terlepas dari aktivitas siswa selama proses pembelajaran berlangsung. Keaktifan siswa tampak pada tiap fase pelaksanaan model pembelajaran inkuiri. Pada fase pertama dan kedua, guru memberikan gambaran mengenai proses pembelajaran dan menampilkan situasi bermasalah atau kejadian yang menarik kepada siswa sehingga siswa aktif dalam mengumpulkan informasi. Pada fase ketiga, siswa aktif merumuskan hipotesis dari apa yang akan diselidiki. Pada fase keempat, siswa mengumpulkan data dengan cara melakukan penyelidikan serta menganalisis data yang telah diperoleh untuk menguji kebenaran dari hipotesis awal. Pada fase terakhir, siswa aktif merumuskan kesimpulan berdasarkan hasil penyelidikan yang telah dilakukan. Secara keseluruhan setiap fase model pembelajaran inkuiri mendukung siswa untuk aktif dalam proses pembelajaran.

Hasil ini juga didukung oleh pernyataan Rustaman (2005) yang menyatakan bahwa model pembelajaran inkuiri dapat menjadikan siswa aktif dalam penyelidikan baik untuk pengetahuan maupun pemahaman untuk memenuhi keingintahuan siswa. Oleh karena itu, melalui proses pembelajaran inkuiri ini siswa dapat mengembangkan kemampuan intelektual, sehingga dengan menggunakan model pembelajaran inkuiri siswa lebih aktif dan hasil belajar siswa lebih tinggi daripada hasil belajar siswa yang diajar dengan pembelajaran konvensional.

Penggunaan media simulasi PhET juga mendukung meningkatnya hasil belajar siswa. Hal ini dikarenakan simulasi PhET membuat pembelajaran lebih menarik dimana siswa dapat belajar sekaligus bermain pada simulasi tersebut. Hal ini senada dengan pernyataan Resmiyanto (2009) yang menyatakan bahwa simulasi PhET merupakan animasi interaktif yang dibuat seperti layaknya permainan dimana 
siswa dapat belajar dengan melakukan eksplorasi. Simulasi-simulasi tersebut menekankan korespondensi antara fenomena nyata dan simulasi komputer kemudian menyajikannya dalam modelmodel konseptual fisis yang mudah dimengerti oleh para siswa. Dengan demikian, penggunaan simulasi PhET sangat mendukung siswa dalam memahami dan menemukan inti materi yang sedang dipelajarinya.

Hasil penelitian ini juga didukung oleh hasil penelitian dari peneliti yang sebelumnya. Berdasarkan hasil penelitian Bukit (2012) dapat disimpulkan bahwa model pembelajaran inkuiri dapat meningkatkan ketuntasan hasil belajar siswa dan model pembelajaran inkuiri juga berhasil memperbaiki aktivitas siswa, dan hasil penelitian Prihatiningtyas, dkk (2013) menyatakan bahwa implementasi simulasi PhET pada pokob bahasan optik dapat menuntaskan hasil belajar siswa.

Selama pelaksanaan penelitian diperoleh bahwa model pembelajaran inkuiri memiliki kelebihan yaitu memberi peluang yang sama kepada semua siswa, baik yang memiliki kemampuan rendah, sedang ataupun tinggi untuk berhasil. Oleh karena itu, semua siswa ditantang untuk dapat menemukan inti materi pembelajaran dengan bantuan bimbingan dari peneliti.

Penggunaan model pembelajaran inkuiri ini dapat meningkatkan aktivitas dan hasil belajar siswa, tetapi selama proses pembelajaran masih ada kendala yang dihadapi, yaitu ada siswa yang belum memahami peran dan tugasnya dalam bekerja kelompok, peneliti juga masih belum mampu memanajemen waktu dengan baik, dan peneliti juga mengalami kendala saat akan menampilkan simulasi PhET, yaitu terjadi pemadaman listrik sehingga simulasi tidak dapat ditampilkan menggunakan proyektor

\section{KESIMPULAN DAN SARAN Kesimpulan}

Adapun kesimpulan dri hasil penelitian ini adalah ada pengaruh yang signifikan model pembelajaran inkuiri menggunakan simulasi PhET terhadap hasil belajar siswa di kelas $\mathrm{X}$ SMAN 2 Kabanjahe T.P. 2014/2015.

\section{Saran}

Saran yang dapat disampaikan peneliti kepada guru mupun peneliti selanjutnya adalah ketika ada siswa yang belum memahami peran dan tugasnya dalam bekerja kelompok, diharapkan kepada guru maupun peneliti selanjutnya agar membimbing siswa dalam mengambil peranan di dalam kelompok praktikum. Peneliti juga menyarankan kepada guru maupun peneliti selanjutnya agar membuat manajemen waktu praktikum dengan baik sehingga proses belajar mengajar berlangsung dengan efektif. Peneliti juga menyarankan kepada guru maupun peneliti selanjutnya yang ingin menggunakan media pembelajaran yang ditayangan menggunakan proyektor sebaiknya tetap mencari alternatif lain apabila terjadi pemadaman arus listrik. Saran yang terakhir, peneliti menyarankan agar guru maupun peneliti selanjutnya agar menggunakan model pembelajaran inkuiri menggunakan simulasi PhET di dalam proses pembelajaran fisika.

\section{DAFTAR PUSTAKA}

Bukit, H., (2012), Perbaikan Aktivitas dan Penguasaan Konsep Fisika Melalui Penerapan Model Pembelajaran Inkuiri pada Siswa Kelas XI IPA 1 SMA Negeri 1 Kabanjahe, Jurnal Penelitian Inovasi Pembelajaran Fisika, 4(1) : 1-6 Juni 2012. (Diakses tanggal 18 September 2013).

Gulo, W., (2002), Strategi Belajar Mengajar, Grasindo, Jakarta.

McKagan, B.S., Perkins, K.K., Dubson, M., Reid, S., LeMaster, and R., Wieman, C.E., (2008), Developing and Researching PhET simulations for Teaching Quantum Mechanics, 
Journal of Applied Physics, (online), 40(1) $1-13$, (http://www.colorado.edu/physics/Ed ucationIssues/papers/QMsims.pdf), diakses 14 Maret 2015.

Prihatiningtyas, S., Prastowo, T., dan Jadmiko, B., (2013), Implementasi Simulasi PhET dan Kit Sederhana untuk Mengajarkan Keterampilan Psikomotor Siswa pada Pokok Bahasan Alat Optik, Jurnal Pendidikan IPA Indonesia, Vol 2(1):1-5. (Diakses tanggal 9 Februari 2015).

Resmiyanto, R., (2009), PhET: Simulasi Fisika untuk Membantu Pembelajaran di Kelas, (http://rachmadresmi.blogspot.com/20 09/03/PhET-simulasi-fisika-untukmembantu.html), diakses pada 15 Agustus 2015.
Rustaman, N.Y., (2005), Perkembangan Penelitian Pembelajaran Berbasis Inkuiri dalam Pendidikan Sains, Seminar Nasional II Juli 2005.

Sabri, A., (2010), Strategi Belajar Mengajar Micro Teaching, Penerbit Quantum Teaching, Ciputat.

Sirait, R., (2012), Pengaruh Model Pembelajaran Inquiry Training Terhadap Hasil Belajar Siswa pada Materi Pokok Usaha dan Energi Kelas VIII MTs N-3 Medan, Jurnal Pendidikan Fisika, Vol. 1 No. 1 Juni 2012, Universitas Negeri Medan. (Diakses tanggal 18 September 2013)

Sudjana, (2005), Metode Statistika, Penerbit Tarsito, Bandung.

Trianto, (2010), Mendesain Model Pembelajaran Inovatif-Progresif, Penerbit Kencana, Jakarta. 